\title{
THE INFLUENCE OF SCURVY ON HEMORRHAGES IN PLAGUE.*
}

\section{W M. B. WHER R .}

(From the Laboralory of the United States Public Health and Marine Hospital Service, Oakland, California.)

Ir is sometimes stated that extensive hemorrhages in plague do not occur so frequently now as in some of the older epidemics. According to Scheube: "In some epidemics especially they are so numerous that the whole body appears black, hence the designation of Black Death."

Hirsch" says with regard to this pandemic "of the middle of the fourteenth century, which, under the name of the Black Death came from the East and overran a large part of the old world": "It follows from the statements of all the chroniclers of this pestilence-medical and non-medical-that spitting of blood was one of the commonest phenomena in the course of the disease." It seems somewhat uncertain as to whether the designation Black Death was derived from the special prevalence of cutaneous hemorrhages, for Hirsch makes the significant statement that "unfortunately the available records of plague are poor in clinical facts; so that it is difficult to come to a definite opinion whether there are any considerable differences between the several epidemics as to the frequency of hemorrhages in general, or as to the particular kinds of hemorrhages."

However, it seems possible that the social misery of the fourteenth century was accompanied by the prevalence of scurvy, a disease which might well contribute to the degree of hemorrhages which occurs in the normal individual. Epidemic scurvy was not recognized by the medical profession until the fifteenth century. Hirsch says: "It is a priori highly probable that scurvy had been epidemic from time to time in antiquity under the same circumstances that have given rise to it in the modern period or in recent times. It certainly follows from the account given by Jacques de Vitry of a disease called by him the plague which ravaged the army of the Crusaders before Damietta in 1218 , and from Joinville's description

\footnotetext{
* Received for publication July 28 , Igog.

- The Diseases of Warm Countries, Phila., 1003, p. 23.

Handbook of Geographical and Historical Pathology, London, $1883-86$, I, p. 540.
} 
of the sickness that broke out in I250 among the army of Louis IX at the siege of Cairo, that scurvy had existed long before we have any medical recognition or description of it as a peculiar form of disease."

I have noted from time to time that different guinea-pigs inoculated by the cutaneous method from different rats or from the same rat showed varying degrees of petechial or periglandular hemorrhages. Notes were kept on the variety of guinea-pigs used and in one series it seemed that the rough haired variety was more prone to hemorrhagic extravasations. However, further observations failed to substantiate that one. The probable explanation was not thought of until I read the "Experimental Studies, Relating to Ship-Beri-Beri and Scurvy" by Holst and Frölich.' Their work showed that when guinea-pigs of 300-600 gm. were kept on a "one sided" diet consisting of various sorts of grain, groats, and bread, they died in I8 days or more from a disease that corresponded, macro- as well as microscopically, to human scurvy. They also proved the favorable influence of various "anti-scorbutics" the value of which has been demonstrated by human experience, such as cabbage, and fresh potatoes. A "onesided" diet of the latter vegetables failed to produce the disease.

I have confirmed their observations as far as most of the gross pathological changes are concerned, altho my naked-eye examination of the osseous system has not been nearly as thorough. Their experiments clearly demonstrate that guinea-pigs rapidly become abnormal when kept on certain single diets and it seems as if these facts should be borne in mind in keeping these animals for experimental purpnses. Before reading their paper, I encountered stock guinea-pigs on two occasions which died of general anasarca with muscular hemorrhages, cases which showed no bacteria on microscopic examination and which now appear to have been guinea-pigs with scurvy.

Experiments were undertaken to determine the influence of scurvy on the general coursc of plague in guinea-pigs with some attempt at determining whether a salt antagonism existed or not. However, the experiments reported here are believed to be merely suggestive and not at all conclusive. A preliminary experiment was conducted as follows:

× Jour. Hyg.1 1907, 7 , p. 634 
Two guinea-pigs, whose initial weight was 385 and $340 \mathrm{gm}$. respectively, which had been kept on a diet of rolled barley and water only for 17 days were inoculated cutaneously with spleen tissue from a guinea-pig dead of acute rat plague and were then kept on a diet of barley and water only. They both died in about 48 hours and on dissection showed buboes which were very much more hemorrhagic than usual in guinea-pigs and the large hemorrhagic extravasations about the buboes extended up along the posterior wall of the pelvis and abdomen. The adrenals were injected and hemorrhagic. There were a few subserous petechiae on the intestines (not unusual). The mesenteric glands showed subcapsular hemorrhages There were a few small hemorrhages about the knee joints. The blood escaping from the vessels was not coagulated in I $_{5}$ minutes. Microscopically there was a marked septicemia with rods resembling $B$. pestis.

Further experiments were conducted as follows:

Series $x$. Ten adult guinea-pigs were kept supplied with a liberal amount of rolled barley and water. On the 23 rd day two, Nos. 2 and 5 , died of scurvy with a loss in weight of 249 and $170 \mathrm{gm}$. respectively. No. 2 showed areas of congestion and grayish discoloration about the roots of the teeth of the lower jaw; a few petechial hemorrhages about the axillary and inguinal glands and into the capsule of the glands, and some diffuse extravasations about the knee and elbow joints; the molar teeth could be removed with ease and their roots were blood stained. No. 5 showed the same changes but the hemorrhages were more marked. On the next day (24th) the remaining pigs were inoculated cutaneously with plague cultures, Nos. I-8, and a control normal stock, No. I I, with a 24 -hour old culture of virulent rat plague which had been isolated three months before; and Nos. 9 , ro, and a control normal stock guinea-pig, No. 12, were inoculated cutaneously with an avirulent plague culture "Bombay." 1

As most of the animals were in a very weak condition they were kept after inoculation on a diet of cabbage and carrots. Within 24 hours most of them had gained in strength visibly.

Table I, p. 568 , shows the loss in weight, time till death, and the anatomical findings in the series.

Series 2. Ten adult guinea-pigs were kept in the same manner as those in Series I, but in addition received daily $8 \mathrm{gm}$. of $\mathrm{CaCl}_{2}$ dissolved in their drinking water. On the $24^{\text {th }}$ day No Io whose initial weight was $388 \mathrm{gm}$. died; it weighed $235 \mathrm{gm}$. and on dissection showed none of the periglandular and periarticular hemorrhages seen in the animals kept on barley and water alone, but its teeth came out readily and there were small hemorrhages into the axillary and inguinal glands. The remaining nine animals were very much stronger and livelier than those kept on barley and water only. Numbers I-6 were inoculated cutaneously with the virulent culture of rat plague used in Series $I$ and at the same time the animals in the first series were inoculated; and Nos. 7-9 with the avirulent culture "Bombay." They were fed on cabbage and carrots after the inoculation.

Table 2, p. 569 , shows the results of these inoculations.

In neither series did the guinea-pigs inoculated with the avirulent culture "Bombay" contract plague.

The degree of hemorrhage which occurred in guinea-pigs 3 and 8 ,

'See McCoy, Jour. Inject. Dis., 1909, 6, p. 170. 
Series $I$, and 6 , Series 2, was very much greater than $I$ have ever seen in guinea-pigs without scurvy. This is also true concerning the guinea-pigs used in the preliminary experiment. Had the animals in Series $\mathrm{I}$ and 2 been inoculated a few days sooner and then been kept on barley and water the results might have more nearly approximated than those obtained in the preliminary experiments.

\section{SUMMARY AND CONCLUSIONS.}

Scorbutic guinea-pigs when inoculated with plague may show a greater degree of hemorrhagic extravasation post mortem, than is usually seen. In a single experiment with two animals, which were kept on barley and water for 17 days, then inoculated with plague and kept on the scorbutic diet, death occurred in about 48 hours; and the coagulation of the blood was scen to be delayed for more than ${ }_{5}$ minutes. In another series where six guinea-pigs were kept on barley and water for 24 days they became so weak that they were fed antiscorbutics, cabbage and carrots, after inoculation with plague; and only two of these animals showed a degree of hemorrhage which could be considered excessive for either plague or scurvy in the guinea-pig.

When six guinea-pigs, kept on the same scorbutic diet for 24 days, received calcium chloride in their drinking water, they kept in better health and only one showed excessive hemorrhage when inoculated with plague.

These experiments are not conclusive but suggestive in showing that there might be excessive hemorrhage when plague and scurvy occur in the same individual. 
TABIE I.

\begin{tabular}{|c|c|c|c|c|c|}
\hline No. & $\begin{array}{l}\text { Initial } \\
\text { Weight in } \\
\text { Grams }\end{array}$ & $\begin{array}{l}\text { No. of } \\
\text { Days till } \\
\text { Death } \\
\text { after Inoc- } \\
\text { ulation }\end{array}$ & $\begin{array}{l}\text { Weight in } \\
\text { in Grams } \\
\text { at Time } \\
\text { of Inocu- } \\
\text { lation }\end{array}$ & $\begin{array}{l}\text { Loss in } \\
\text { Weight in } \\
\text { Grams }\end{array}$ & Remarks \\
\hline I........ & 630 & 6 & $5 \pm 5$ & II 5 & $\begin{array}{l}\text { Chloroformed in a sickly condition; } \\
\text { large slightly congested buboes; large } \\
\text { speck led spleen; numerous consoli- } \\
\text { dated areas, } 2-3 \mathrm{~mm} \text {. in diameter, in } \\
\text { lungs. }\end{array}$ \\
\hline $3 \ldots \ldots$ & $53^{\circ}$ & 4 & $44^{\circ}$ & 90 & $\begin{array}{l}\text { Good general condition; marked local } \\
\text { reaction at left of median line; sero- } \\
\text { gelatinous exudate over abdomen; } \\
\text { large left inguinal bubo surrounded by } \\
\text { very marked periglandular bemorrha- } \\
\text { ges; intestines covered with petechiae; } \\
\text { spleen large and soft and full of foci } \\
\text { of necrosis; liver congested and full of } \\
\text { foci of neirosis; lungs normal; left } \\
\text { pelvic glands enlarged and deeply } \\
\text { congested; right inguinal gland of } \\
\text { normal size but slightly congested, a } \\
\text { few small petechiae in fascia about } \\
\text { right knee joint, none about left knee } \\
\text { joint. }\end{array}$ \\
\hline $4 \ldots \ldots \ldots$ & 640 & $-\mathrm{I}$ & 340 & $3^{00}$ & $\begin{array}{l}\text { Not infected; marked scurvy; numer- } \\
\text { ous diffuse subcutaneous and cutane- } \\
\text { ous hemorrhages } 6 \text { to } \mathrm{I2} \mathrm{mm} \text {. in } \\
\text { diameter about sides and back. }\end{array}$ \\
\hline $6 \ldots \ldots$ & 510 & $-I$ & 325 & 185 & $\begin{array}{l}\text { Not infected; marked scurvy; small } \\
\text { hemorrhages in the skin and about } \\
\text { knee joints. }\end{array}$ \\
\hline 7 & 460 & 2.5 & 287 & I 73 & $\begin{array}{l}\text { No local reaction; small left inguinal } \\
\text { bubo with slight periglandular hemor- } \\
\text { rhage; secondary left pelvic bubo with } \\
\text { numerous capsular petechiae; numer- } \\
\text { ous petechiae in both axillary regions } \\
\text { and under serosa of lungs; spleen } \\
\text { large, soft, and deeply congested; } \\
\text { large sub-facial hemorrhages about } \\
\text { thighs and knee joints. }\end{array}$ \\
\hline $8 \ldots \ldots$ & $48 I$ & 4.5 & 328 & 533 & $\begin{array}{l}\text { Good local reaction; cutaneous hemor- } \\
\text { rhages } 3 \mathrm{~mm} \text {. in diameter about an } \\
\text { inch distant from local reaction; large } \\
\text { left inguinal bubo with very marked } \\
\text { hemorrhagic extravasations which ex- } \\
\text { tend down over left knee joint; large } \\
\text { irregularly shaped hemorrhagic ex- } \\
\text { travasation in right axilla; spleen large } \\
\text { and speckled; liver congested; lungs } \\
\text { pale and show a few petechine; in- } \\
\text { testines covered with petechiae; slight } \\
\text { serous ascites. }\end{array}$ \\
\hline II control & $44 \mathrm{I}$ & 4.5 & $44 \mathrm{I}$ & $\cdots$ & $\begin{array}{l}\text { Kept on normal diet of cabbage and bar- } \\
\text { ley until inoculation; periglandular } \\
\text { hemorrhage almost as marked as in } \\
\text { No. 8, but not as marked as in No. } 3 \text {; } \\
\text { no hemorrhages away from bubo. }\end{array}$ \\
\hline
\end{tabular}


TABLE 2.

\begin{tabular}{|c|c|c|c|c|c|}
\hline No. & $\begin{array}{c}\text { Initial } \\
\text { Weight in } \\
\text { Grams }\end{array}$ & $\begin{array}{l}\text { No. of } \\
\text { Days till } \\
\text { Death } \\
\text { after Inoc- } \\
\text { ulation }\end{array}$ & $\begin{array}{l}\text { Weight in } \\
\text { Grams at } \\
\text { Time of } \\
\text { of Inocu- } \\
\text { lation }\end{array}$ & $\begin{array}{l}\text { Loss in } \\
\text { Weight in } \\
\text { Grams }\end{array}$ & Results \\
\hline r........ & $46 r$ & 4.5 & $35^{8}$ & 103 & $\begin{array}{l}\text { Good local reaction; left inguinal bubo } \\
\text { not very large but well congested; } \\
\text { good periglandular exudate; spleen } \\
\text { and liver speckled. }\end{array}$ \\
\hline $2, \ldots \ldots$ & 519 & $3 \pm$ & 366 & 153 & $\begin{array}{l}\text { Small but typical local reaction with } \\
\text { small cutaneous hemorrhages; good } \\
\text { right inguinal bubo surrounded by } \\
\text { marked hemorrhages; small deeply } \\
\text { congested left inguinal bubo; spleen } \\
\text { large, soft, and full of foci of necrosis; } \\
\text { quite marked hemorraghic extravasa- } \\
\text { tions about both knee joints; liver } \\
\text { deeply congested. }\end{array}$ \\
\hline 3. & 564 & $4 \cdot 5$ & 462 & 102 & $\begin{array}{l}\text { Typical plague but not much periglan- } \\
\text { dular hemorrhage; no hemorrhage } \\
\text { about joints; in good physical condi- } \\
\text { tion. }\end{array}$ \\
\hline $4 \cdots$ & 505 & $3 \pm$ & 523 & + & $\begin{array}{l}\text { In better general condition than most of } \\
\text { the others; marked local reaction and } \\
\text { marked hemorrhage about bubo; } \\
\text { serous ascites; no hemorrhages } \\
\text { about knee joints. }\end{array}$ \\
\hline $5 .$. & 426 & $3 \pm$ & 317 & 109 & $\begin{array}{l}\text { No local reaction; double buboes sur- } \\
\text { rounded by marked hemorrhages; } \\
\text { no hemorrhages about the knee } \\
\text { joints. }\end{array}$ \\
\hline $6 \ldots \ldots$. & 475 & $3 \pm$ & 358 & 117 & $\begin{array}{l}\text { Marked local reaction; whole left bubo } \\
\text { and groin is filled by a large hemor- } \\
\text { rhage, about } 2 \text { inches in diameter, and } \\
\text { hemorrhages extend down the left } \\
\text { thigh and about the knee joint; the } \\
\text { hemorrhage on the left side extends } \\
\text { into the pelvis and the left pelvic gland } \\
\text { is intensely hemorrhagic; numerous } \\
\text { petechiae over intestines; few about } \\
\text { right knee joint. }\end{array}$ \\
\hline
\end{tabular}

